\title{
A VALIDATED TLC- DENSITOMETRY FOR THE SIMULTANEOUS DETERMINATION OF TAMSULOSIN AND DUTASTERIDE IN THEIR COMBINED PHARMACEUTICAL FORMULATION.
}

\author{
Ahmed E. Abbas* ${ }^{2}$, Sherif M. Eid ${ }^{2}$, Ahmed Serag ${ }^{1}$, Khalid A.M. Attia ${ }^{1}$ \\ ${ }^{1}$ Department of Pharmaceutical Analytical Chemistry, Faculty of Pharmacy, Al-Azhar \\ University, Nasr City, Cairo, Egypt. \\ ${ }^{2}$ Department of Analytical chemistry, Faculty of Pharmacy, October 6 University, 6 \\ October City, Giza, Egypt.
}

\section{Corresponding Author Email: ahmed.emad.pha@o6u.edu.eg}

\begin{abstract}
A TLC densitometric method was developed and validated for simultaneous determination of dutasteride and tamsulosin in their challenging combined pharmaceutical formulation, where the separation process was achieved using a mobile phase composed of ethyl acetate: methanol: hexane: ammonia (90: 5: 3: 2 by volume) on pre-coated silica gel (60 GF254) plates, densitometric quantification was performed at $270 \mathrm{~nm}$ for both drugs. TAMS and DUTA were resolved with Rf values of $0.57 \pm 0.01$ and $0.72 \pm 0.01$ with a mean percentage recovery of $100.51 \pm 0.659$ and $100.81 \pm 0.743$, respectively. Method validation was performed following the International Conference on Harmonization (ICH) guidelines and was victoriously applied for simultaneous determination of tamsulosin $\mathrm{HCl}$ and dutasteride in their pharmaceutical formulation. The acquired results of the Proposed method were statistically compared with those acquired by the reported methods, demonstrating no significant difference. Therefore, the proposed method has the potential for being fast, simple, economic, and selective for sustainable analysis of the cited drugs.
\end{abstract}

Keywords: Tamsulosin; Dutasteride; TLC; binary mixture; Densitometry; chromatography 


\section{1 | Introduction}

Nowadays, benign prostatic hyperplasia (BPH) is the most prevailing urological disease in men after middle age (Foo, 2019). The Combination therapy with tamsulosin and dutasteride is more effective than monotherapy with moderate-to-severe lower urinary tract symptoms (LUTS) due to benign prostatic hyperplasia and prostatic enlargement (Roehrborn et al., 2010). In 2021, tamsulosin is the 32nd most widely prescribed medication in the United States, while dutasteride was the 288th most often prescribed medication (The Top 300 of 2021, n.d.).

Tamsulosin hydrochloride (TAMS), 5-[(2R)-2-[2-(2-ethoxyphenoxy) ethyl amino] propyl]-2 methoxy benzene sulfonamide hydrochloride as shown in (Figure. 1). It is sparingly soluble in water and methanol, slightly soluble in glacial acetic acid and ethanol, and practically insoluble in ether (Dunn et al., 2002). It is a selective $\alpha 1$-adrenoreceptor blocking agent prescribed for improving urinary obstruction and alleviate the symptoms of benign prostatic hyperplasia by preventing the sympathetic excitation of smooth muscle tone in the prostate and bladder neck (Laurence L. Brunton et al., 2018).

Dutasteride (DUTA), $\quad(5 \alpha, 17 \beta)-\mathrm{N}-\{2,5$ bis $\quad$ (trifluoromethyl)phenyl $\}-3-o x o-4-$ azaandrost-1-ene-17-carboxamide as shown in (Figure. 1). It is soluble in ethanol (44 $\mathrm{mg} / \mathrm{mL})$, methanol $(64 \mathrm{mg} / \mathrm{mL})$, and polyethylene glycol $400(3 \mathrm{mg} / \mathrm{mL})$, but it is insoluble in water (Keam \& Scott, 2008). It is a specific inhibitor of both, type 1 and type 2 isoforms of $5 \alpha$-reductase enzyme, an intracellular enzyme that converts the androgen testosterone into $5 \alpha$-dihydrotestosterone hormones that cause prostatic hypertrophy, Therefore, In males with an enlarged prostate, a combination of both medications is proper for the treatment of symptomatic benign prostatic hyperplasia (Nandana et al., 2021).

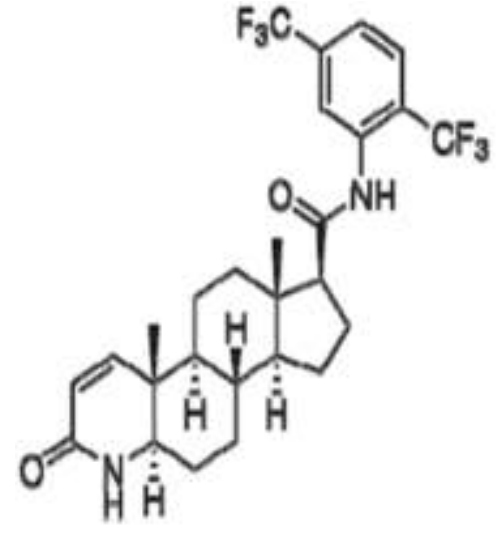

A

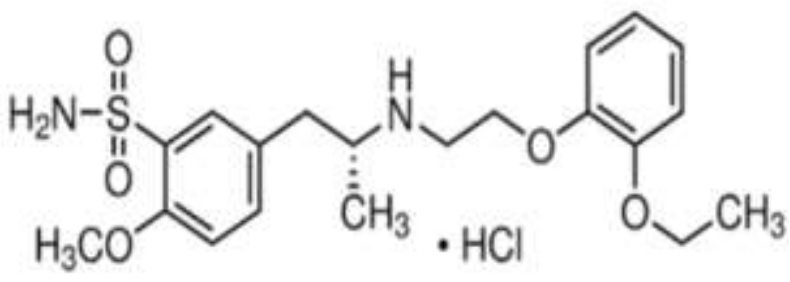

B

Fig. 1. Structure of the studied compounds, DUTA (A) and TAMS (B) 
Interestingly, owing to the wide clinical potential of TAMS/DUTA, simple and cost-effective analytical methods are necessitating for quantitative determination in their combined dosage form. The literature survey revealed the following analytical techniques concerned with the determination of TAMS/DUTA mixture: Reported spectrophotometric methods for the simultaneous determination of TAMS/DUTA mixture include dualwavelength Method, simple simultaneous equation method, first-order derivative, and areas under the curve. Furthermore many other methods include HPLC (Mohammed Ishaq et al., 2014; Nagaraju et al., 2017; Shrivastava \& Aggrawal, 2013). However, the reported methods have some limitations including high consumption of solvents, long analysis run time, and high cost. Alternatively, the TLC-densitometric technique can tackle all these limitations of the previously published methods with intensified simplicity and efficacy for drug analysis. It provides a cost-efficient, fast, simple, and automated technique for the identification, separation, and quantification of complex mixtures with extraordinary resolution and reproducibility (Jeya Shakila et al., 2001) To the best of our knowledge, no TLC-densitometric method was published for the cited drugs in their challenging binary mixture. Hence, this work aimed to develop the first simple, accurate, sensitive, robust, and precise TLC-densitometric method for the separation and simultaneous determination of the TAMS/DUTA in their dosage form. Furthermore and to present the Method validation basing on regulatory requirements as per the International Conference on Harmonization (ICH) guidelines such as linearity, selectivity, precision, accuracy, and robustness (ICH Steering Committee, 1996).

\section{2 | Experimental}

\section{1 | Apparatus}

TLC densitometer: CAMAG TLC auto-sampler Linomat IV (Switzerland) was used for data collection. equipped with a $100-\mu \mathrm{L}$ CAMAG microsyringe (Hamilton, Bonaduz, Switzerland) that is employed for the sample application. The following parameters were adjusted, (the scanning mode is absorbance mode, the scanning speed is $20 \mathrm{~mm} / \mathrm{s}$, the slit dimension is $3 \mathrm{~mm} \times 0.45 \mathrm{~mm}$, and the resulting output is chromatogram and integrated peak area). Sampling was carried out on TLC aluminum plates $(20 \times 20 \mathrm{~cm})$, pre-coated with $0.25 \mathrm{~mm}$ silica gel (60 GF254) (Fluka Chemie, Switzerland).

\subsection{Reagents and materials}

\subsection{1 | Pure standards}

Pure TAMS and DUTA were kindly supplied by GlaxoSmithKline Pharmaceutical Company (Fifth district- New Cairo, Egypt). Their purity was $(99.25 \%)$ and $(99.7 \%)$ respectively (Mohammed Ishaq et al., 2014). 


\subsection{2 | Pharmaceutical dosage form}

Duodart ${ }^{\mathrm{TM}}$ capsule, batch number 4009759A, manufactured by (GlaxoSmithKline Pharmaceutical company, Cairo, Egypt). Which is labeled to contain (400 $\mu$ g of TAMS and $500 \mu \mathrm{g}$ of DUTA) per capsule was purchased from a local pharmacy.

\subsubsection{Chemicals and reagents}

All chemicals and solvents were of pure analytical grade. Hexane, Methanol, ethyl acetate, and Ammonia solution $33 \%$ were purchased from (El-Nasr Pharmaceutical Chemicals Co. Abu- Zabaal, Cairo, Egypt).

\section{3 | Standard solutions}

Stock standard solution of TAMS $(1.0 \mathrm{mg} / \mathrm{ml})$ and DUTA $(1.0 \mathrm{mg} / \mathrm{ml})$ were prepared by separately dissolving $10 \mathrm{mg}$ of each drug in $5 \mathrm{ml}$ methanol into two $10-\mathrm{ml}$ volumetric flasks as TAMS is sparingly soluble in methanol then each flask was accurately completed to $10 \mathrm{ml}$ using the same solvent. All stock and working solutions were stored in a refrigerator $\left(4-8^{\circ} \mathrm{C}\right)$ and reserved against light until use.

\section{4 | Procedures}

\subsection{1 | Chromatographic condition}

Chromatographic separation was implemented on a stationary phase of precoated silica gel 60 F254 TLC aluminum plates that were split into smaller plates of the size $20 \times$ $10 \mathrm{Cm}$. The superior mobile phase for chromatographic separation was ethyl acetate: methanol: hexane: ammonia (90: 5: 3: 2 by volume) conveyed to the developing chromatographic tank pre-saturated with the selected mobile phase for $30 \mathrm{~min}$ at ambient temperature $25 \pm 2{ }^{\circ} \mathrm{C}$. the photometric measurements of the generated bands were performed at $270 \mathrm{~nm}$ in the absorption mode at scanning speed $20 \mathrm{~mm} / \mathrm{s}$ using Wincats software for data measurement, collection, and analysis. Thereafter, concentrations of TAMS and DUTA in the generated bands manifested as peak areas in the TLCdensitometric chromatograms.

\subsubsection{Linearity and construction of calibration graphs}

Aliquots from TAMS and DUTA stock solution $(1 \mathrm{mg} / \mathrm{ml})$ were accurately spotted onto TLC plates to deliver 0.2-4 $\mu \mathrm{g}$ / Spot for each drug employing an automatic spotter with $100 \mu \mathrm{l}$ micro syringe under a nitrogen stream to form bands $(6 \mathrm{~mm}$ length, $10 \mathrm{~mm}$ spacing, and $10 \mathrm{~mm}$ from the bottom edge of the plate). Then the procedure described under the chromatographic condition was followed using $50 \mathrm{ml}$ of the mobile phase containing ethyl acetate: methanol: hexane: ammonia (90:5:3: 2 by volume). The plates were linearly developed for a mobile phase migration distance of $7 \mathrm{~cm}$. Thereafter, the TLC 
plates were removed and air-dried for about $5 \mathrm{~min}$. Then bands were scanned at $270 \mathrm{~nm}$ in the absorption mode. The calibration curves were developed by plotting the peak areas versus analyte concentrations and the regression equations were finally computed. Parameters of system suitability and validation were accordingly checked and evaluated. Accuracy was measured three times using five concentrations $(1,1.5,2,3$, and $4 \mu \mathrm{g} / \mathrm{band})$ for both drugs. Three concentrations of both drugs $(1,2$, and $4 \mu \mathrm{g} / \mathrm{band})$ were measured three times either intra-daily for assessing "repeatability" or inter-daily for investigating "intermediate precision". Robustness was checked by intentional alteration of the saturation time of the TLC chamber and changing the Traveling distance.

\subsubsection{Assay of laboratory prepared mixtures}

Aliquots from TAMS and DUTA stock solution $(1 \mathrm{mg} / \mathrm{ml})$ indicating several mixtures with various ratios were accurately spotted onto TLC plates following the abovementioned specific chromatographic conditions and scanned at $270 \mathrm{~nm}$. The concentration for each component was calculated using its regression equation

\subsubsection{Application of the proposed method for qualification of TAMS and DUTA in Duodart $^{\mathrm{TM}}$ capsules and standard addition technique}

Contents of 20 Duodart ${ }^{\mathrm{TM}}$ capsule was finely powdered and an amount equivalent to one capsule ( $400 \mu \mathrm{g}$ of TAMS and $500 \mu \mathrm{g}$ of DUTA) was extracted three times with $25 \mathrm{ml}$ of methanol, filtered through a $0.45 \mu \mathrm{m}$ PTFE syringe filter (13 mm diameter) into $100 \mathrm{ml}$ volumetric flask then the volume was adjusted with the same solvent to obtain a solution labeled to contain $(0.4 \mu \mathrm{g} / \mathrm{ml}$ TAMS and $0.5 \mu \mathrm{g} / \mathrm{ml}$ DUTA) (Table 3). The procedures were completed as previously described to calculate the concentration of the two drugs using the regression equations. To apply a standard addition technique, various amounts of standard TAMS and DUTA were added to accurately weighed portions of the Duodart ${ }^{\mathrm{TM}}$ capsule.

\section{$3 \mid$ Results and discussion}

\section{1 | Method optimization}

The selection of the appropriate mobile phase for a successful TLC separation process is based on controlled trials and error methods and a literature survey (Choudhari \& Nikalje, 2009; Monir et al., 2020; D. Patel \& Patel, 2010). Several solvent systems of several compositions and several percentages of each component were tried. Interestingly, the better separation that gets sharp symmetric separated peaks, optimum migration, acceptable $\mathrm{Rf}$ values with perfect resolution, and more sensitive quantitative analytical process was attained using a mobile phase composed of ethyl acetate: methanol: hexane: ammonia (90: 5: 3: 2 by volume). The Rf values were $0.57 \pm 0.01$ and $0.72 \pm 0.01$ for TAMS and DUTA, respectively as shown in (Fig. 2 \&. 3). Even saturation of the TLC chamber for $30 \mathrm{~min}$ with the mobile phase asserted better resolution and better precision. Furthermore, saturation is a significant Step to guarantee atmospheric homogeneity and 
reduce solvent evaporation from the TLC plate (Abdelwahab \& Abdelaleem, 2013). Different scanning wavelengths at $270 \mathrm{~nm}$ and $279 \mathrm{~nm}$ were tried to acquire better sensitivity and reduce noise. The scanning of the bands at wavelength $270 \mathrm{~nm}$ was noticed to be the best regarding the sensitivity of TAMS and DUTA.

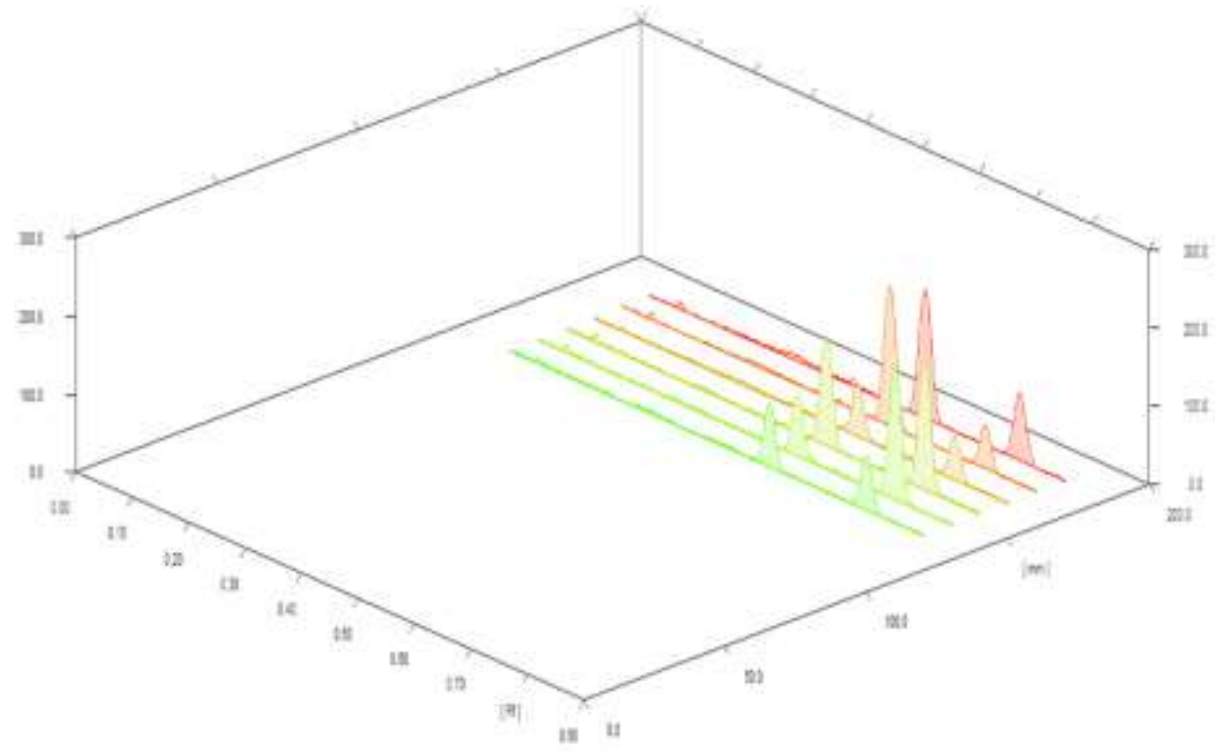

Fig. 2. Three dimensions TLC chromatogram showing the separation of TAMS $(0.4-1.5$ $\mu \mathrm{g} /$ spot $)$ from DUTA $(0.5-1.5 \mu \mathrm{g} /$ spot $)$ at RF $=0.57 \pm 0.01$ and $0.72 \pm 0.01$, respectively at $270 \mathrm{~nm}$

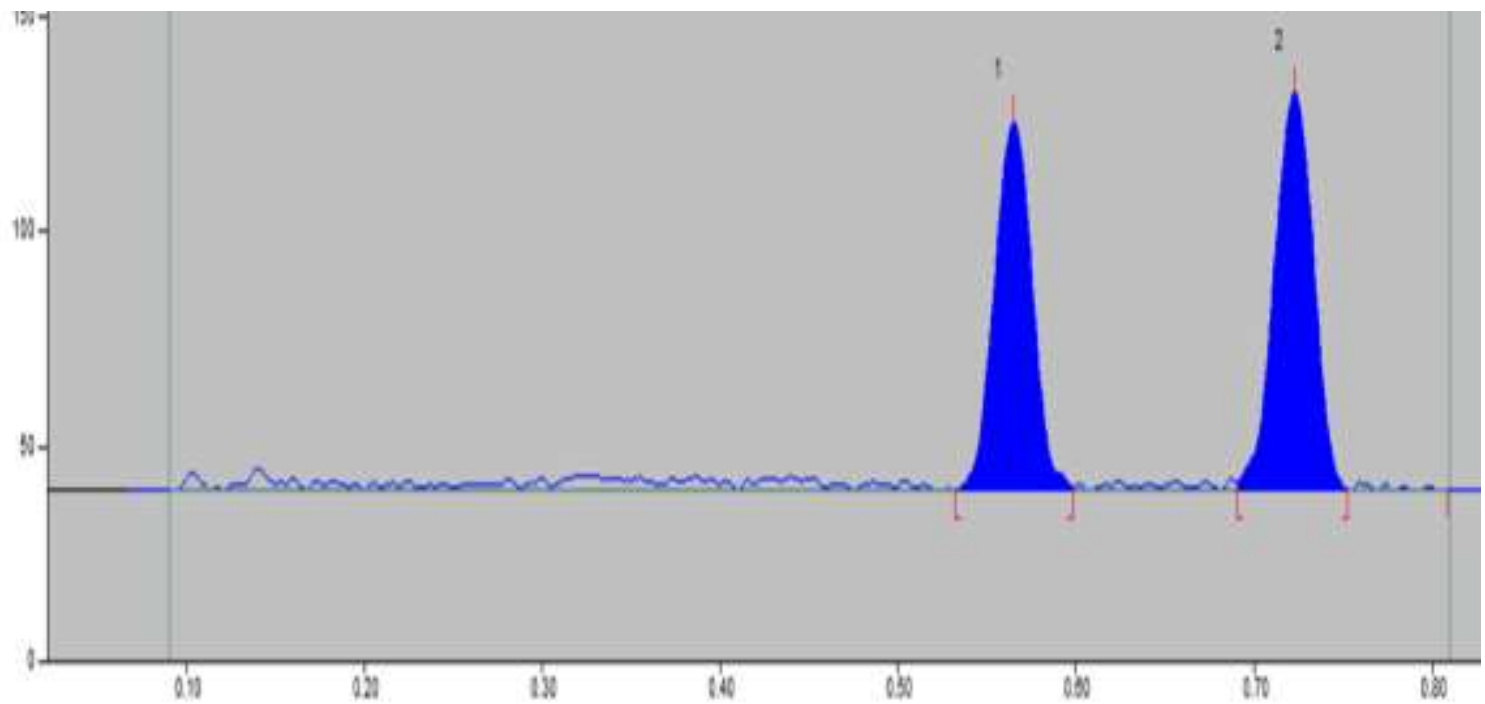

Fig. 3. Two dimensions TLC chromatogram showing the separation of TAMS ( $0.9 \mu \mathrm{g} /$ spot) from DUTA $(1 \mu \mathrm{g} / \mathrm{spot})$ at $\mathrm{Rf}=0.57 \pm 0.01$ and $0.72 \pm 0.01$, respectively at $270 \mathrm{~nm}$ 


\section{2 | System suitability parameters}

According to ICH, system suitability tests are part and parcel of many analytical methods, particularly chromatographic methods. Parameters including capacity factor $\left(\mathrm{K}^{\prime}\right)$, symmetry factor (S), resolution factor (Rs), and selectivity factor $(\alpha)$ (Boltia et al., 2021) were calculated To decide if the operating system was performed appropriately. Intriguingly, The proposed TLC-densitometric method showed satisfactory values in the acceptable ranges as summarized in (Table 1). Therefore, they verify that the resolution and reproducibility of The proposed TLC-densitometric method are appropriate for the analysis to be well-done.

Table 1: Parameters of system suitability of the developed TLC method.

\begin{tabular}{|l|l|l|l|l|}
\hline Parameters & TAMS & & DUTA & Reference values \\
\hline Retardation factor (Rf) & 0.57 & & 0.72 & \\
\hline${\text { Capacity factor }\left(\mathrm{K}^{\prime}\right)^{\mathrm{a}}}^{\mathrm{e}}$ & 0.75 & & 0.39 & $0-10$ \\
\hline Symmetry factor(S) & 1.05 & & 1.03 & $\approx 1$ \\
\hline${\text { Resolution }(\mathrm{Rs})^{\mathrm{c}}}^{\mathrm{a}}$ & & 3.60 & & Rs $>2$ \\
\hline Selectivity factor $(\alpha)^{\mathrm{b}}$ & & 1.92 & & $\alpha>1$ \\
\hline${\text { Theoretical plate number }(\mathrm{N})^{\mathrm{d}}}^{\mathrm{a}}$ & 1600 & & 1730 & \\
\hline
\end{tabular}

${ }^{a}$ the capacity factor $\left(K^{\prime}\right)=(1-\mathrm{Rf}) / \mathrm{Rf}$.

${ }^{\mathrm{b}}$ Selectivity factor $(\alpha)=\mathrm{k}^{\prime} 2 / \mathrm{k}^{\prime} 1$.

${ }^{\mathrm{c}}$ Resolution $(\mathrm{Rs})=[2(\mathrm{Rf} 2-\mathrm{Rf} 1)] /(\mathrm{W} 1+\mathrm{W} 2)$, where $\mathrm{Rf}$ is retardation factor and $\mathrm{W}$ is peak width at $5 \%$ from the baseline of the peak height.

${ }^{\mathrm{d}}$ Theoretical plate number $(\mathrm{N})=16(\mathrm{z} / \mathrm{w})^{2}$, where $\mathrm{z}$ is the migration length of the spot and $\mathrm{w}$ is the spot width.

${ }^{\mathrm{e}}$ Symmetry factor(S) $=\mathrm{w} / 2 \mathrm{f}$, where $\mathrm{w}$ is peak width at $5 \%$ from the baseline of the peak height and $\mathrm{f}$ is the distance along that horizontal line from the leading edge of the peak to the vertical line

\section{3 $\mid$ Method validation}

Method validation was applied according to the International Conference on Harmonization (ICH) guidelines (ICH Steering Committee, 1996). 


\subsection{1 | Linearity/Range}

A linear relationship was obtained between the area under the peak and the selected concentration range of 0.2 to $4 \mu \mathrm{g} \mathrm{band}^{-1}$ for each drug. The linear regression equation was found to be

$\mathrm{Y} 1=2181.9 \mathrm{C} 1+525.11 \quad\left(\mathbf{r}^{2}=0.9997\right)$ for TAMS $($ Fig. 4$)$

$\mathrm{Y} 2=2214.5 \mathrm{C} 2+604.80 \quad\left(\mathbf{r}^{2}=0.9998\right)$ for DUTA $($ Fig. 5$)$

Where Y1 and Y2 are the integrated peak areas for TAMS and DUTA respectively, $\mathrm{C} 1$ and $\mathrm{C} 2$ are the corresponding concentrations in $\mu \mathrm{g} / \mathrm{band}$ for TAMS and DUTA respectively and $\mathbf{r}^{2}$ is the determination coefficient. The low intercept values and the high values of the determination coefficients indicated good linearity of the proposed method. The determination coefficient, $y$-intercept, slope, and correlation coefficient were presented in Table 2.

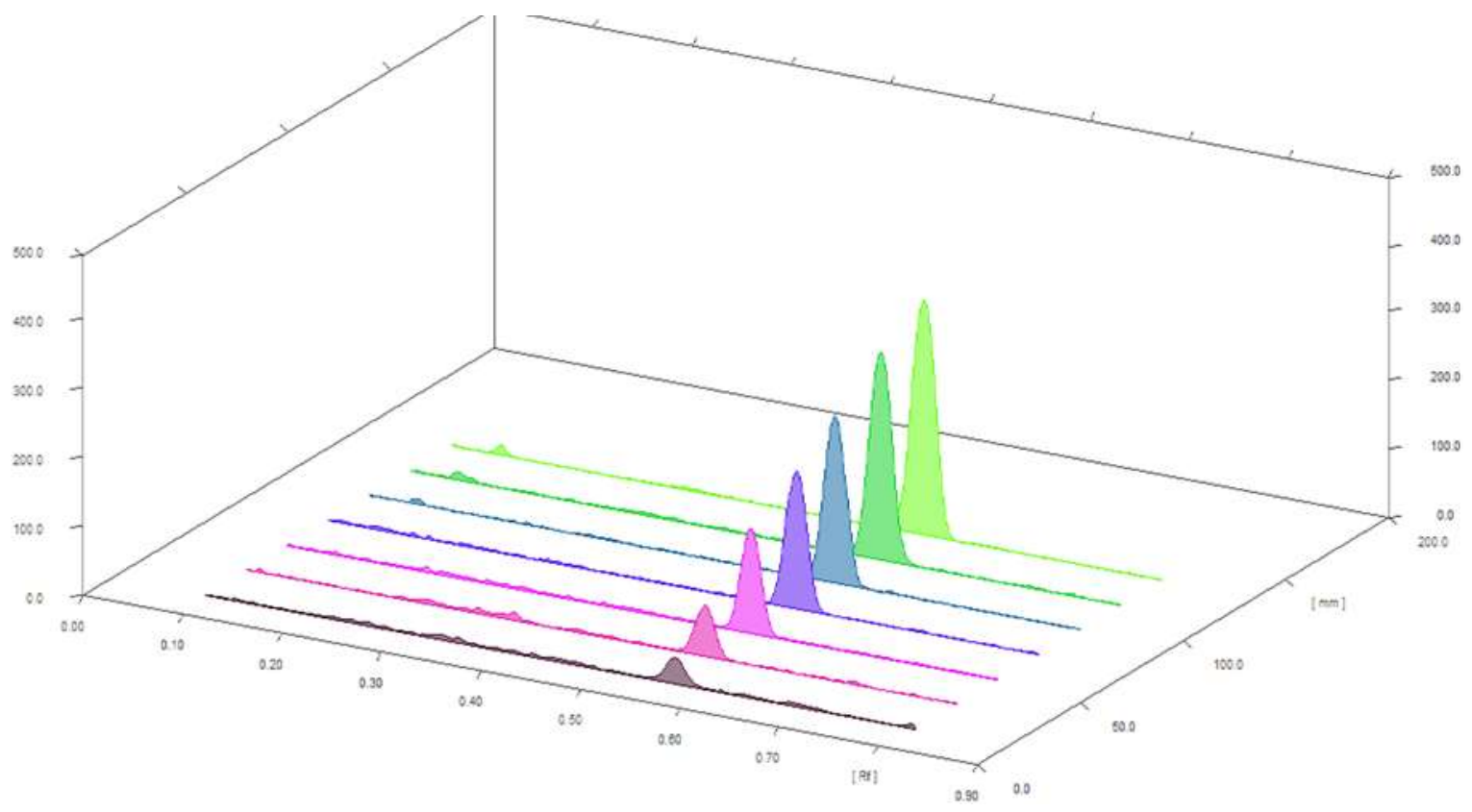

Fig. 4. Three dimensions TLC chromatogram showing TAMS linearity range $(0.2-4 \mu \mathrm{g} /$ spot) at $\mathrm{Rf}=0.57 \pm 0.01$ at $270 \mathrm{~nm}$ 


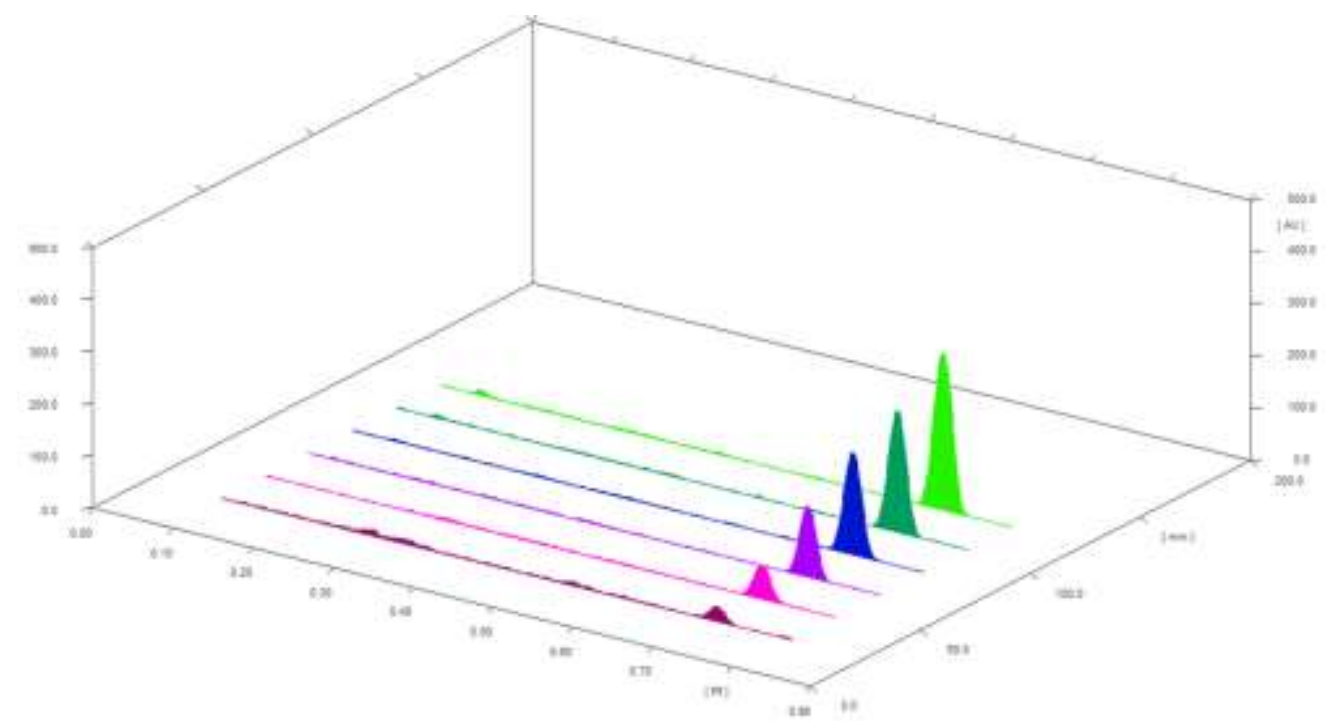

Fig. 5. Three dimensions TLC chromatogram showing DUTA linearity range $(0.2-4 \mu \mathrm{g} /$ spot) at $\mathrm{Rf}=0.72 \pm 0.01$ at $270 \mathrm{~nm}$

\subsection{2 | Sensitivity (LOD and LOQ)}

The sensitivity of the suggested methods is determined by calculating the limit of detection (LOD) and limit of quantitation (LOQ). they were calculated according to ICH guidelines by an approach based on the standard deviation of the response and the slope. The results are presented in (Table 2). the following equations: $\mathrm{LOD}=3.3 \sigma / S$ and LOQ = $10 \sigma / S$, have been used, where $\sigma$ is the standard deviation of the response and $S$ is the slope of the linearity The small values of LOD and LOQ signalize good sensitivity.

\subsection{3 $\mid$ Accuracy}

The pharmaceutical active ingredients (TAMS and DUTA) were assayed following the developed TLC method to demonstrate accuracy using Three replicate determinations of five different concentrations of linearity ranges 0.2 to $4 \mu \mathrm{g}$ band -1 for each drug, $n=5$ for each level. The concentrations were then calculated from the corresponding regression equations. Accuracy as mean percent recovery ( $\% \mathrm{R})$ was calculated. The satisfying mean recovery percent for each drug confirms the good accuracy of The proposed TLCdensitometric method (Table 2).

\subsection{4 | Precision}

Repeatability(intra-day); Three replicate determinations of three chosen concentrations of TAMS and DUTA in pure forms within the linearity range were investigated on the same day. The precision of the proposed method was expressed in terms of $\%$ relative standard deviation (\% RSD), where The satisfying values of $\%$ relative standard deviation (\% RSD)for each drug imply the good repeatability of The proposed 
TLC-densitometric method (Table 2). Intermediate precision; the same concentrations were calculated over a period of 3 days (inter-daily) employing the same procedures and \% RSD for the measuring peak area was found to be less than $2 \%$, ensuring appropriate functioning of the TLC system and satisfying intermediate precision (Table 2).

\subsection{5 $\mid$ Robustness}

Robustness was checked by evaluating the influence of deliberate variations in the method parameters. e.g.: changing Traveling distance $\pm 0.5 \mathrm{~cm}$ and changing saturation time \pm 2 min. No appreciable effect on system suitability parameters was observed. And The method was found to be robust depending on smaller RSD values, as shown in (Table 2).

\subsubsection{Specificity}

The specificity of the proposed TLC-densitometric method was proven by applying it to six laboratory-prepared mixtures that were prepared with different ratios of TAMS and DUTA along with their linearity ranges(Fig. 6). The obtained values were satisfactory as shown in (Table 2). therefore, it is considered to be specific and selective.

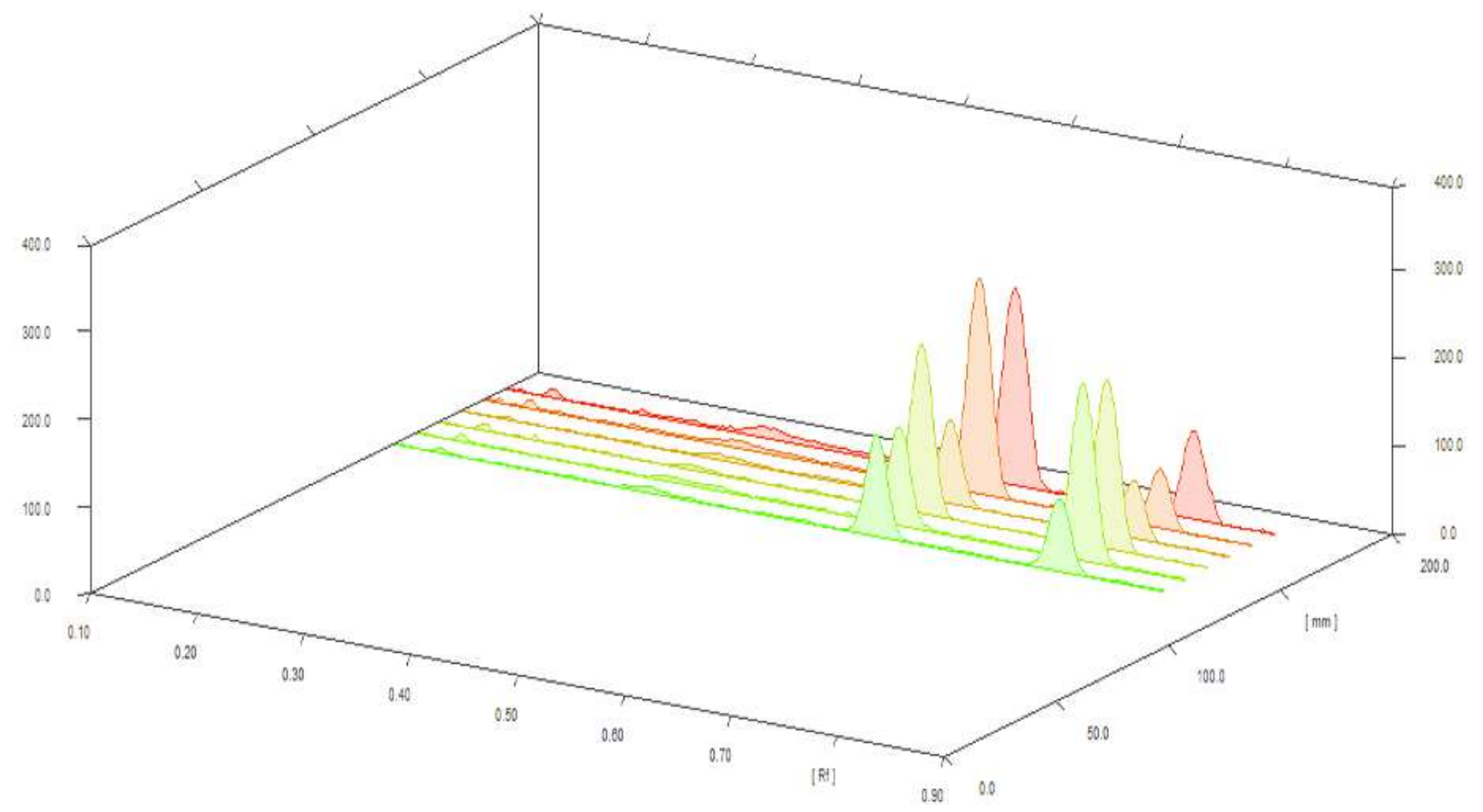

Fig. 6. six laboratory-prepared mixtures that were prepared with different ratios of TAMS and DUTA along with their linearity ranges at $270 \mathrm{~nm}$ 
Table 2: Method validation parameters for determination of TAMS and DUTA by the two proposed TLC-densitometric method

\begin{tabular}{|c|c|c|}
\hline Parameter & TAMS & DUTA \\
\hline Range $(\mu \mathrm{g} / \mathrm{band})$ & 0.2 to $4 \mu \mathrm{g} \mathrm{band}^{-1}$ & 0.2 to $4 \mu \mathrm{g}_{\text {band }}{ }^{-1}$ \\
\hline Determination coefficient $\left(\mathrm{r}^{2}\right)$ & 0.9997 & 0.9998 \\
\hline Correlation coefficient (r) & 0.99985 & 0.9999 \\
\hline Intercept & 525.11 & 604.8 \\
\hline Slope & 2181.9 & 2214.5 \\
\hline LOD $(\mu \mathrm{g} /$ band $)$ & 0.0010011 & 0.001116 \\
\hline LOQ ( $\mu \mathrm{g} /$ band $)$ & 0.003034 & 0.003383 \\
\hline Accuracy (mean \pm RSD) & $100.51 \pm 0.659$ & $100.81 \pm 0.743$ \\
\hline Robustness $^{\mathrm{a}}$ (RSD) & 0.397591 & 0.370684 \\
\hline \multicolumn{3}{|l|}{ Precision (RSD) } \\
\hline Repeatability & 0.685536 & 0.585416 \\
\hline Intermediate precision & 0.463077 & 0.816159 \\
\hline Specificity $^{\mathrm{b}}($ mean \pm RSD $)$ & $101.55 \pm 0.273$ & $100.19 \pm 0.866$ \\
\hline
\end{tabular}

${ }^{a}$ RSD of determination of three concentrations of each drug after changing Traveling distance $\pm 0.5 \mathrm{~cm}$ and changing saturation time $\pm 2 \mathrm{~min}$.

${ }^{\mathrm{b}}$ Average of determinations in six laboratory prepared mixtures.

\subsection{Application of the proposed TLC-densitometric method for assaying of Duodart $^{\mathrm{TM}}$ capsules}

The proposed TLC-densitometric method was successfully applied for the determination of TAMS and DUTA in Duodart ${ }^{\mathrm{TM}}$ capsules. TAMS and DUTA were selectively and simultaneously quantified without interference from the excipients. Moreover, a standard addition technique was applied to check the validity of the proposed method. The satisfying values obtained, confirmed no interference from the excipients and additives (Table 3 ).

\section{5 | Statistical analysis}

The results of the proposed TLC-densitometric method for the determination of TAMS and DUTA were statistically compared with those obtained by the reported method. Both Student's t-test and F-test indicated that there was no appreciable difference between the proposed and reported method (Ganthi et al., 2016)(D. B. Patel et al., 2010) regarding accuracy and precision (Table 4). 
Table 3: Quantitative estimation of TAMS and DUTA in their pharmaceutical formulation and application of standard addition technique

$\underline{\text { Standard addition technique }}$

\begin{tabular}{|c|c|c|c|c|c|}
\hline Product & Drug & Found $(\%)^{\mathrm{a}} \pm$ RSD & Taken & added & Recovery $(\%)^{b}$ \\
\hline \multirow{8}{*}{$\begin{array}{l}\text { Duodart }{ }^{\mathrm{TM}} \text { capsule, } \\
400 \mu \mathrm{g} \text { of TAMS } \\
\text { and } 500 \mu \mathrm{g} \text { of } \\
\text { DUTA }\end{array}$} & \multirow{4}{*}{ TAMS } & \multirow{4}{*}{$98.31 \pm 0.476$} & \multirow{4}{*}{0.4} & 0.2 & 98.15 \\
\hline & & & & 0.5 & 101.48 \\
\hline & & & & 1 & 102.399 \\
\hline & & & & $\begin{array}{l}\text { Mean } \pm \\
\text { RSD\% }\end{array}$ & $\begin{array}{l}101.03 \pm \\
1.630\end{array}$ \\
\hline & \multirow{4}{*}{ DUTA } & \multirow{4}{*}{$100.799 \pm 0.951$} & \multirow{4}{*}{0.5} & 0.2 & 100.08 \\
\hline & & & & 0.5 & 102.34 \\
\hline & & & & 1 & 101.199 \\
\hline & & & & $\begin{array}{l}\text { Mean } \pm \\
\text { RSD\% }\end{array}$ & $101.21 \pm 1.117$ \\
\hline
\end{tabular}

${ }^{\mathrm{a}}$ Average of three determinations of capsule dosage form solution.

${ }^{\mathrm{b}}$ Average of three determinations.

Table 4: Statistical comparison of the results obtained by the proposed TLC-densitometric method and reported HPLC methods for the analysis of TAMS and DUTA.

\begin{tabular}{|l|l|l|l|l|}
\hline & \multicolumn{3}{|l|}{ Proposed TLC-densitometric method } & \multicolumn{2}{l|}{ reported methods $^{\text {a }}$} \\
\hline Parameter & TAMS & DUTA & TAMS $^{\text {a }}$ & DUTA $^{\text {b }}$ \\
\hline Mean of recoveries & 100.51 & 100.81 & 100.05 & 99.59 \\
\hline SD & 0.662 & 0.749 & 1.093 & 1.018 \\
\hline Variance & 0.438 & 0.561 & 1.195 & 0.626 \\
\hline $\mathrm{N}$ & 5 & 5 & 5 & 5 \\
\hline $\begin{array}{l}\text { Student's t-test } \\
(2.306)\end{array}$ & 0.798 & 1.973 & & \\
\hline $\begin{array}{l}\text { F-test } \\
(6.388)\end{array}$ & & & & \\
\hline
\end{tabular}

${ }^{\mathrm{a}}$ HPLC method using C18 $(150 \times 4.6 \mathrm{~mm}, 3.5 \mu \mathrm{m}$ particle size $)$ column, a mobile phase of acetonitrile-buffer (prepared by transferring $0.1 \mathrm{~g}$ octane sulfonic acid sodium salt and 1.0 
$\mathrm{ml}$ phosphoric acid into $1.0 \mathrm{~L}$ water; $20: 80, \mathrm{v} / \mathrm{v}$ ), the flow rate of $1.5 \mathrm{ml} / \mathrm{min}$ and detection wavelength of $225 \mathrm{~nm}$ (Ganthi et al., 2016)

${ }^{\mathrm{b}}$ HPLC method using C18 column $(250 \mathrm{~mm} \times 4.6 \mathrm{~mm}, 5 \mu \mathrm{m}$ particle size $)$ column, mobile phase of methanol:water $(90: 10 \mathrm{v} / \mathrm{v})$, flow rate of $1 \mathrm{ml} / \mathrm{min}$ and detection wavelength of 235 nm (D. B. Patel et al., 2010)

${ }^{\mathrm{c}}$ The values in parentheses represent the corresponding tabulated values of $\mathrm{t}$ and $\mathrm{F}$ at $\mathrm{p}=$ 0.05 .

\section{4 | CONCLUSION}

A simple sensitive and selective TLC densitometric method has been developed for simultaneous determination of TAMS and DUTA in their pure forms and the pharmaceutical preparation. The method was validated according to regulatory requirements as per the ICH guidelines. The developed TLC-densitometric method if compared to the reported methods, it has the extensive advantage of being more sensitive and selective. Moreover, this TLC-densitometric method can offer a simple alternative to the reported HPLC method when HPLC requirements are unavailable. The developed method is time-saving where several samples can be spotted and developed at the same time. This method is also cost-effective since a small amount of mobile phase was used, unlike HPLC procedures. Finally, we can conclude that the recommended TLCdensitometric procedure can be used in routine analysis of TAMS and DUTA in their pure forms and pharmaceutical dosage form without previous separation. subsequently, this method will economize both cost and time and can be utilized in quality-control laboratories.

\section{REFERENCES}

Abdelwahab, N., \& Abdelaleem, E. (2013). TLC-densitometric determination of guaifenesin, pseudoephedrine hydrochloride and guaifenesin related substance (Guaiacol). Journal of Planar Chromatography - Modern TLC, 26(1), 73-77. https://doi.org/10.1556/JPC.26.2013.1.11

Boltia, S. A., Abdelkawy, M., Mohamed, T. A., \& Mostafa, N. N. (2021). Eco-friendly RP-HPLC and HPTLC Methods for Simultaneous Determination of Tamsulosin Hydrochloride and Deflazacort in the Presence of 21-Hydroxy Deflazacort and Testing the In-vitro Dissolution of the Combined Dosage Form via RP-HPLC Method. Chromatographia, 84(3), 285-295. https://doi.org/10.1007/s10337-02104009-y

Choudhari, V. P., \& Nikalje, A. P. (2009). Stability-indicating TLC method for the determination of dutasteride in pharmaceutical dosage forms. Chromatographia, 70(1-2), 309-313. https://doi.org/10.1365/s10337-009-1108-x 
Dunn, C. J., Matheson, A., \& Faulds, D. M. (2002). Tamsulosin: A review of its pharmacology and therapeutic efficacy in the management of lower urinary tract symptoms. Drugs and Aging, 19(2), 135-161. https://doi.org/10.2165/00002512200219020-00004

Foo, K. T. (2019). What is a disease? What is the disease clinical benign prostatic hyperplasia ( $\mathrm{BPH})$ ? World Journal of Urology, 1-4. https://doi.org/https://doi.org/10.1007/s00345-019-02691-0

Ganthi, H. K. R., P, R. R., Park, Y. J., Bapatu, H. R., Park, S. J., \& Cho, W. H. (2016). Stability Indicating HPLC Method for Quantification of Solifenacin Succinate \&amp; Tamsulosin Hydrochloride along with Its Impurities in Tablet Dosage Form. American Journal of Analytical Chemistry, 07(11), 840-862. https://doi.org/10.4236/ajac.2016.711073

ICH Steering Committee. (1996). ICH Harmonised tripartite guideline, validation of analytical procedures: methodology. Methodology, 1994(November 1996).

Jeya Shakila, R., Vasundhara, T. S., \& Kumudavally, K. V. (2001). A comparison of the TLC-densitometry and HPLC method for the determination of biogenic amines in fish and fishery products. Food Chemistry, 75(2), 255-259. https://doi.org/10.1016/S0308-8146(01)00173-X

Keam, S. J., \& Scott, L. J. (2008). Dutasteride A Review of its Use in the Management of ProstateProstate Disorders. 68(4), 463-485.

Laurence L. Brunton, Hilal-Dandan, R., \& Knollmann, B. C. (2018). Goodman \& Gilman's: The Pharmacological Basis of Therapeutics (P. Laurence L. Brunton, P. of P. and Medicine, S. D. School of Medicine, University of California, C. La Jolla, Editors, P. Randa Hilal-Dandan, L. in Pharmacology, S. D. School of Medicine, University of California, C. La Jolla, P. Björn C. Knollmann, MD, W. S. P. of M. and Pharmacology, V. C. for A. R. and T. Director, D. of C. Pharmacology, V. U. S. of Medicine, \& T. Nashville (Eds.); 13th ed.). Cenveo® Publisher Services. https://accessmedicine.mhmedical.com/book.aspx?bookID=2189\#165936881

Mohammed Ishaq, B., Vanitha Prakash, K., \& Krishna Mohan, G. (2014). Simultaneous determination of dutasteride and tamsulosin in pharmaceutical dosage forms by RP-HPLC. Der Pharma Chemica, 6(3), 103-109.

Monir, H. H., Ali, A. M., Refat, R. E., \& Abbas, S. S. (2020). Chromatographic Methods for Determination of Finasteride and Tamsulosin Hydrochloride and in Presence of Finasteride Degradation Product. Acta Chromatographica, 32(2), 95-101. https://doi.org/10.1556/1326.2019.00577 
Nagaraju, P., Prasad, B. D., \& Priyadarshini, G. I. (2017). Development and validation of a Reversed Phase HPLC method for simultaneous determination of Tamsulosin and Dutasteride in tablet dosage form. Advance Pharmaceutical Journal, 2(4), 134-138.

Nandana, P. I., Adipura, L. R., \& Rasyid, A. H. (2021). The effect of tamsulosin and dutasteride combination drug therapy on prostate volume in patients with benign prostatic hyperplasia. IOP Conference Series: Earth and Environmental Science, 712(1). https://doi.org/10.1088/1755-1315/712/1/012024

Patel, D. B., Patel, N. J., Patel, S. K., Prajapati, A. M., \& Patel, S. A. (2010). RP-HPLC method for the estimation of dutasteride in tablet dosage form. Indian Journal of Pharmaceutical Sciences, 72(1), 113-116. https://doi.org/10.4103/0250474X.62247

Patel, D., \& Patel, N. (2010). Validated RP-HPLC and TLC methods for simultaneous estimation of tamsulosin hydrochloride and finasteride in combined dosage forms. Acta Pharmaceutica, 60(2), 197-205. https://doi.org/10.2478/v10007-010-0013-z

Roehrborn, C. G., Siami, P., Barkin, J., Damia, R., Nandy, I., Morrill, B. B., Gagnier, R. P., \& Montorsi, F. (2010). Corrigendum to "“ The Effects of Combination Therapy with Dutasteride and Tamsulosin on Clinical Outcomes in Men with Symptomatic Benign Prostatic Hyperplasia: 4-Year Results from the CombAT Study" [ Eur Urol 2010 ; 57 : 123 - 31 ] e. EUROPEAN UROLOGY, 58, 75390. https://doi.org/10.1016/j.eururo.2010.07.035

Shrivastava, A., \& Aggrawal, P. (2013). Various Analytical Methodologies for Determination of Selective $\alpha$ 1A Receptor Blocker Tamsulosin Hydrochloride and Its Combinations in Different Matrices. World Journal of Analytical Chemistry, 1(3), 37-48. https://doi.org/10.12691/wjac-1-3-3

The Top $\mathbf{3 0 0}$ of 2021. (n.d.). Retrieved June 21, 2021, from https://clincalc.com/DrugStats/Top300Drugs.aspx 


\section{تطبيق طريقة كرموتوغر افيا الفصل بالطبقة الرقيقة لتحديد كلا من التامسولوسين والدوتاستير ايد في

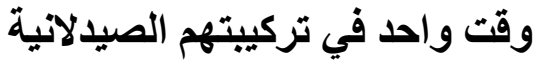$$
\text { "أحمد عماد عباس ,' أحمد سر أج, شريف محمد عيد, 'خالد عبد السلام }
$$$$
\text { ' قسم الكيمياء التحليلية الصيدلانية، كلية الصيدلة، جامعة الأزهر، مدينة نصر، القاهرة، مصر. }
$$$$
\text { r طسم الكيمياء التحليلية ، كلية الصيدلة، جامعه } 7 \text { أكتوبر، مدينه } 7 \text { أكتوبر، الجيزه ، مصر }
$$$$
\text { ahmed.emad.pha@o6u.edu.eg : البريد الالكتروني للباحث الرئيسي }
$$

لقد تم تطبيق طريقه كرموتوغر افيا الفصل بالطبقه الرقيقه و التحقق من صحتها لتحديد في وقت وته و احد كلا من

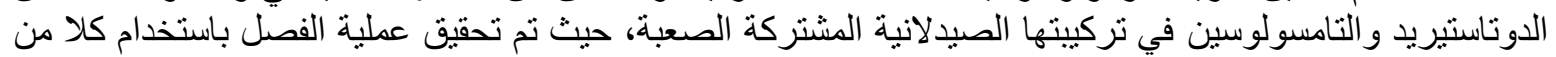

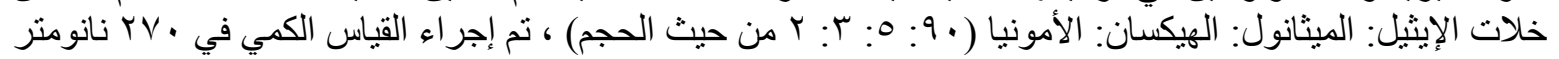

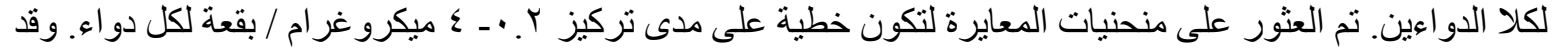

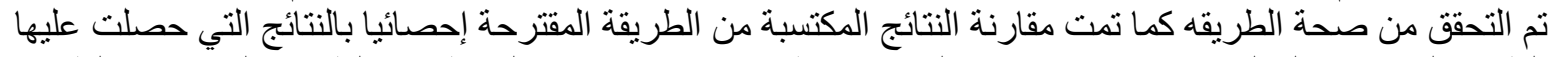

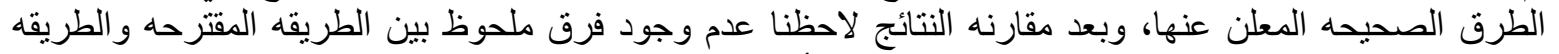

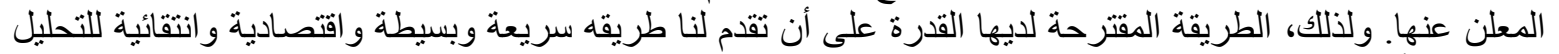
المستدام للادوية المذكورة.

الكلمات المفتاحيه : الدوتاستيريد” التامسولوسين ‘ خليط ثنائي ، كرمونو غر افيا الفصل بالطبقه الرقيقه 